\title{
COMPARATIVE STUDY OF ELEMENT COMPOSITION OF SOME HONEY SAMPLES IN IBADAN METROPOLIS
}

\author{
ADAMS, B.A, OSIKABOR B, OLOMOLA A AND ADESOPE, A. A. A. \\ College of Forestry, Jericho, Ibadan, Nigeria \\ Corresponding author's Email: adamcinjoy@yahoo.com
}

\begin{abstract}
The study was carried out at the Federal College of Forestry, Ibadan with seven honey samples were randomly selected within Ibadan metropolis, labeled as: Sample A (Forestry Honey), Sample B(Pure Honey), Sample C (Mr. Honey), Sample D (Taraba Honey), Sample $E$ (Sokoto Honey), Sample F (Saki Honey), and Sample G (Natural Honey). The samples were then analysed at the chemical laboratory of the International Institute of Tropic Agriculture (IITA). The TXRF and infrared spectrophotometer techniques were used to measured elemental concentrations present in the sample. Eight elements $-\mathrm{K}, \mathrm{Ca}, \mathrm{P}, \mathrm{Fe}$, $\mathrm{Mn}, \mathrm{Cu}, \mathrm{Zn}$, and $\mathrm{Na}$ - were analysed. The result showed the honey samples to be quite rich in minerals. Potassium was the most abundant element in the honey samples (range 6.629$7.744 \mathrm{ppm}$ ) with a mean value of 7.029, followed by Na (range $0.86-1.13 \mathrm{ppm}$ ) with a mean value of 1.03 and $P$ (range $0.565-0.644 \mathrm{ppm}$ ) with a mean of 0.605. Calcium ranges between 0.277 and 0.591 ppm with a mean value of 0.384 , while Mn has a range of 0.025 $0.036 \mathrm{ppm}$ with a mean of 0.030, followed by $\mathrm{Zn}$ (range 0.02-0.03ppm) with a mean value of $0.03 \mathrm{ppm}$. iron also ranges between 0.015 and $0.024 \mathrm{ppm}$ with a mean value of $0.018 \mathrm{ppm}$, while $\mathrm{Cu}$ came last with a range of 0.001-0.003 and a mean value of 0.002ppm. The computation of the standard deviation shows Potassium to have a value of 0.344, Ca 0.078, P0.023, Fe0.003, $\mathrm{Mn} \mathrm{0.003,} \mathrm{Cu} 0.001, \mathrm{Zn} 0.006$ and $\mathrm{Na}$ 0.476. In addition, the processed honey samples had more elemental concentrations than the unprocessed honeys. Nevertheless the results have shown that Nigeria honey samples are rich in mineral composition, hence the need for better processing method and packaging in order to achieve wide market and income both locally and internationally.
\end{abstract}

Key words: element composition, honey

\section{INTRODUCTION}

Bee, as the source of honey, is one of the hidden non-timber forest products. The importance of bees in boosting agricultural productivity cannot be over-emphasized. Honey bee belong to the order Hymenoptera and is one of the Apis family. It is an insect that lives in almost every part of the world. They are social insects, which lives in colonies cooperating, practicing divistion of labour and existing only as a member of a compound organism. There are 10,000 species of bees in the world and Apis mellifera adansonii is the species of bee prevalent in the West Africa sub-region. A colony of honey bee consist of the queen bee, a fertilized female capable of laying a thousand or more eggs daily. It also consists of a few to 60,000 sexually undeveloped famales called worker bees and from few to a thousand male bees or drones. The female of the bee species is equipped with a venomous sting (Alabi, 2000). Pure natural honey contains $80 \%$ sugar and $20 \%$ water. Honey contains large proportion of dextrose, lexulose and sucrose forming $85 \%$ of honey (Irid, 1985). Honey is a sweet viscose liquid of golden colour manufactured from the world's ancient, most efficient factor - the bee hive (Alabi, 2000).

The characterization of honey would aid the understanding of its properties and applications - medicinal properties, anti-bactrial and anti-oxidant behaviour, and hence its use as a food ingredient in human diet. Some studies on the healing effects and ant microbial 
activity of Nigeria honey on burns and wounds have been reported (Adesunkanmi and Oyelami, 1994). It has been shown to contain large amounts of a wide array of vitamins, minerals, amino acids anti- oxidants which have shown to contain beneficial and healing properties for the skin. It has anti-bacterial properties which have been shown to help clear infections in wounds, reduce pain and scarring. Its ability to lock moisture into the skin is another reason for its popularity as an ingredient for beauty products. In addition, this invaluable food item is a source of instant energy, as it produces abut $9 \%$ of energy when digested, and only an infinitesimal proportion is lost during absorption. It is recommended for all, both the ill and healthy people alike. It is of paramount importance that the honey be pure-adulterated honey being unacceptable. As far as practicable, the honey must be free of organic or inorganic matters foreign to its composition, such as mould, insect, insect debris, brood or grains of sand. In addition, honey should not have odours. It should also not have begun to ferment or have heated to such an extent that its natural enzymes are destroyed or made inactive and have an artificial change (Oluwalana et al., 2001).

Honey, it has been discovered, contains elements like Potassium, Sulphur, Sodium, Calcium, Phosphorus, Iron, Manganese, Copper, Magnesium, Zinc and many others. All these are very important to the human body as they each play a role in the normal functioning of the body. Potassium plays an important role in mental health, while sodium maintains osmotic pressure of body fluid. Calcium is responsible for the formation of strong bones and teeth. Phosphorus is needed for bone development and aids energy for contraction of vertebrate muscle. Iron is needed for hemoglobin formation, while sulphus is essential for formation of protein constituents. Other elements also contribute to maintaining the healthy status of the body. (Oladele, 1999).

Whereas, there are large volumes of data on the characterization of honeys from North America, Europe, Australia, India and South Africa, there is a paucity of data on Nigeria honeys. Honey is farmed and used all over Nigeria. Initially, local farmers harvested the honey from the wild but today apiculture is a growing industry in many parts of the country. (Adebiyi et al., 2004). It has also been observed that virtually most people prefer the imported honey might be of better quality, therefore reducing marketability level of our own honey. In view of this, this study is designed to carry out analysis of elemental (Mineral) contents of selected locally made honey sample.

\section{METHODOLOGY}

\section{Procurement of Honey Samples}

A total of seven samples of honey were randomly selected at various locations in Ibadan and labeled as show below:

$\begin{array}{lll}\text { SAMPLE A } & - & \text { FORESTRY HONEY IBADAN } \\ \text { SAMPLE B } & - & \text { PURE HONEY } \\ \text { SAMPLE C } & - & \text { MR. HONEY } \\ \text { SAMPLE D } & - & \text { TARABA HONEY } \\ \text { SAMPLE E } & - & \text { SOKOTO HONEY } \\ \text { SAMPLE F } & - & \text { SAKI HONEY } \\ \text { SAMPLE G } & - & \text { NATURAL HONEY }\end{array}$

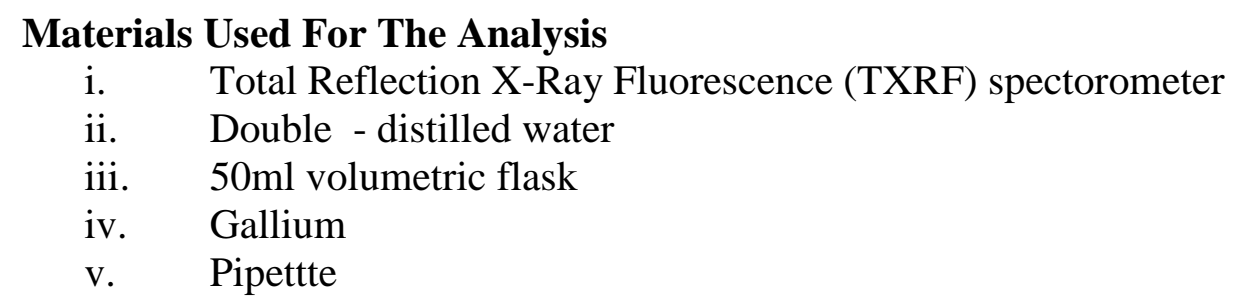


vi. Clean quartz sample carrier

vii. Infrared lamp

\section{Elemental Analysis}

The elemental analysis of the honey sample was performed using the Total Reflection x-Ray Fluorescence (TXRF) spectrometer in the chemical laboratory of the international Institute of Tropical Agriculture. The TXRF spectrometer consist of a COMPACT 3K5 X-ray generator with X-ray tube with a Mo anode. $0.050 \mathrm{~g}$ of each honey sample was dissolve with double distilled - distilled water. Gallium was added to 50NL aliquot of the dissolved sample as internal standard and thoroughly homogenized by shaking. Then 5NL of the solution was pipetted on a clean quartz sample carrier and dried by evaporation under an infrared lamp. The carrier with the dried sample on it was then presented to the TXRF spectrophotometer fro proper identification of elements and their various concentrations.

\section{Data Analysis}

The results obtained were subjected to two analytical tool: the Mean (x) and Standard Deviation (sd). The mean (x) was used to calculate the average value of each element in each of the honey samples, while standard deviation (sd) was used to measure the deviations of each element value from the mean for all the honey samples.

\section{RESULTS AND DISCUSSION}

From Table 1, the Potassium (K) concentration of the honey samples fall with ing the rage of $6.629 \mathrm{ppm}-7.744 \mathrm{ppm}$ with a mean of $7.029 \mathrm{ppm}$. sample B has the highest value of 7.744 while honey $\mathrm{G}$ had the lowest value of $6.629 \mathrm{ppm}$. they are all above the standard recommended range of $0.132-168 \mathrm{ppm}$. The concentration of Calcium $(\mathrm{Ca})$ in $\mathrm{ppm}$ of the honey sample falls with the rage of $0.277-0.519 \mathrm{ppm}$ with a mean value fo $0.384 \mathrm{ppm}$. Sample B also has the highest concentration value while sample D has the lowest concentration value of $00.277 \mathrm{ppm}$. They are all above the standard recommended range of $0.045-0.092 \mathrm{ppm}$ (CODEX, 1991).

The concentration of Phosphorous (P) in ppm of the honey samples falls within the range of $00.565-0.644$ with a mean value of $0.605 \mathrm{ppm}$. The sample with the highest concentration value is sample A while B had the lowest value. They are within the range of standard recommendation of $0.19-0.63 \mathrm{ppm}$. The concentration of $\operatorname{Iron}(\mathrm{Fe})$ of the honey samples falls within the range of $0.015 \mathrm{ppm}-0.024 \mathrm{ppm}$. The mean value is $0.018 \mathrm{ppm}$. Sample A has the highest concentration value while sample D, E and G shows equal lowest concentration value. They are below the standard recommended range of $0.033-0.833 \mathrm{ppm}$.

Table 1: Showing the K, Ca, P and Fe analysis for the seven honey samples

\begin{tabular}{llllll}
\hline Sample & K & Ca & P & Fe & \\
\hline A & 6.872 & 0.43 .4 & 0.644 & 0.024 & FCF \\
B & 7.744 & 0.519 & 0.599 & 0.018 & Pure honey \\
C & 7.234 & 0.385 & 0.621 & 0.019 & Mr. honey \\
D & 6.744 & 0.277 & 0.565 & 0.015 & Taraba honey \\
E & 7.036 & 0.420 & 0.601 & 0.015 & Sokoto honey \\
F & 6.942 & 0.365 & 0.611 & 0.017 & Saki honey \\
G & 6.629 & 0.291 & 0.593 & 0.015 & Natural \\
& & & & & honey \\
Mean & 7.029 & 0.384 & 0.605 & 0.018 & \\
Sd & 0.344 & 0.078 & 0.023 & 0.003 & \\
\hline
\end{tabular}

\footnotetext{
*Concentrations of elements are given in parts per million (ppm).
} 
From Table 2, the range of the Manganese $(\mathrm{Mn})$ concentration of honey samples is between $0.025 \mathrm{ppm}-00.036 \mathrm{ppm}$. In this case, sample $\mathrm{G}$ has the lowest concentration value, while sample A has highest concentration value. The mean value is $0.030 \mathrm{ppm}$. they also rise above the standard recommended range of $0.005-0.01 \mathrm{ppm}$ (CODEX, 1991).

Most honey samples shares the same value for Copper $(\mathrm{Cu})$ concentration. Sample A, $\mathrm{C}, \mathrm{F}$, and $\mathrm{G}$ have the lowest concentration value of $0 . .001 \mathrm{ppm}$, while sample $\mathrm{E}$ has highest concentration value of $0.003 \mathrm{ppm}$. the mean is $0.002 \mathrm{ppm}$. They fall below th standard recommended range of $0.015-0.50 \mathrm{ppm}$. Sample A, B, C and G shared the same value of Zinc $(\mathrm{Zn})$ concentration, which is $0.03 \mathrm{ppm}$, while samples $\mathrm{D}, \mathrm{E}$ and $\mathrm{F}$ has a concentration of $0.02 \mathrm{ppm}$. As for Sodium (Na), sample E had the highest concentration of 1.13ppm followed closely by sample A with $1.12 \mathrm{ppm}$, and sample D recorded the lowest value of $0.86 \mathrm{ppm}$.

From the computation of the standard deviation $(\mathrm{Sd})$, it could be seen that Potassium (K) has a value of 0.344, Ca 0.078, P 0.023, Fe 00.003, Mn 0.003, Cu 0.001, Zn 0.006 and Na 0.476. Altogether, the results show that these examples of Nigeria honeys are quite rich in minerals.

Interestingly, the result showed that unprocessed honeys (Sample D,E and F) contain similar values with process honey samples (A, B,C,G) in elemental quality. But notwithstanding, the results have shown the honey the honey sample to be rich in mineral composition.

This results confirmed the findings of (Adesunkanmi, Oyelami, 1994) that Nigeria honey samples contain large amounts of a wide array of mineral, among other chemical properties, which have been shown to contain beneficial and healing properties for the body.

Table 2: $\quad$ Showing the $\mathrm{Mn}, \mathrm{Cu}, \mathrm{Zn}$ and $\mathrm{Na}$ analysis for the seven honey samples

\begin{tabular}{lllll}
\hline Sample & Mn & Ca & Zn & Na \\
\hline A & 0.036 & 0.001 & 0.030 & 1.120 \\
B & 0.028 & 0.002 & 0.030 & 1.030 \\
C & 0.033 & 0.001 & 0.030 & 0.980 \\
D & 0.029 & 0.002 & 0.020 & 0.860 \\
E & 0.031 & 0.003 & 0.020 & 1.130 \\
F & 0.027 & 0.001 & 0.020 & 1.020 \\
G & 0.025 & 0.001 & 0.030 & 1.030 \\
Mean & 0.030 & 0.002 & 0.030 & 1.030 \\
Sd & 0.003 & 0.001 & .0 .006 & 0.476 \\
\hline
\end{tabular}

Concentrations of elements are given in parts per million (ppm).

\section{CONCLUSION AND RECOMMENDATIONS}

The TXRF and infrared spectrophotometer techniques were use to measure elemental concentrations present in seven honey samples purchased within Ibada metropolis. Eight elements $-\mathrm{K}, \mathrm{Ca}, \mathrm{P}, \mathrm{Fe}, \mathrm{Mn}, \mathrm{Cu}, \mathrm{Zn}$ and $\mathrm{Na}$ - were analyzed. The honey samples were quite in minerals, potassium was the most abundant element in the honeys (range 6.629-7.744), While $\mathrm{Cu}$ had the least concentration value ranging between 0.001 to $0.003 \mathrm{ppm}$ and with a mean value of $0.002 \mathrm{ppm}$. The computation of standard Deviation ( $\mathrm{Sd}$ ) shows potassium to have a value of 0.344, $\mathrm{Ca} 0.078, \mathrm{P} 0.023, \mathrm{Fe} \mathrm{0.0003,} \mathrm{Cu} 0.001, \mathrm{Zn} 0.006$ and $\mathrm{Na} \mathrm{0.476.} \mathrm{This}$ result also showed that the processed honey sample contains a higher elements concentration than the unprocessed honeys. Since sample A has more concentration of four of the eight elements analyzed, (i.e P, Fe, Mn, Zn), it is theefore recommended that sample A (Forestry Honey) should be consumed most than the other honey samples.

For Nigeria to have a place in the list of official honey exporters, it is necessary that the qualities of honey produced in the country be determined. The result of such analysis will 
help in the formulation of policies on bee keeping and honey production in Nigeria. Theefore it is necessary to adopt a better processing and packaging in order to achieve wide market and income both locally and internationally.

\section{REFERENCES}

Adebiyi, F.M., Akpan, I., Obiajuwa, E.I(2004): Chemical /Physical characterization of Nigeria honey. Pakistan journal of nutrition 3(5): 278 - 281.

Adesunkanmi, K. and O.A. Oyelami (1994): The pattern and Outcome of burn injuries at Wesley Guide Hospital, Ilesha, Nigeria : a review of 156 cases. J. Trop. Med. Hyg. $97: 108-112$.

Alabi, J.A. (2000): Bee keeping at glance Odumatt press Nigeria. pp. 1-25.

CODEX (1991): Proceedings from $18^{\text {th }}$ session of the Codex alimentarius commission step 8. $\mathrm{p} 21$.

Iridi, O. (1985): Temperance Enterprises/National Root Crop Research Institute, Umudike unpublished manuscript, Royal Jelly for people who want children. P5.

Oladele, J.O. (1999): Essentials of Senior School Certificate Biology. Pp 31 - 32. pub: Johns Lad publishers Ltd., Lagos

Oluwalana, S.A., S.A. Onadeko, M.O. Folarin (2002): Analysis of honey samples in Abeokuta for composition criteria.. the Nigeria Journal of Forestry vol. 31, no 2. forestry Association of Nigeria ISBN $978-2408-08-9$ p.59.

Richard (1999): Bee keeping as a business. Common wealth secretariat common wealth secretariat Marlborough House Pall Mail, London SWIYSHS United Kingdom. Pp 19-24 